International Journal of Advanced Education and Research

ISSN: 2455-5746; Impact Factor: RJIF 5.34

Received: 25-05-2020; Accepted: 09-06-2020; Published: 18-06-2020

www.alleducationjournal.com

Volume 5; Issue 3; 2020; Page No. 77-81

\title{
Impact of Covid-19 on higher education in India
}

\author{
Pravat Kumar Jena \\ Assistant Regional Director, IGNOU Regional Centre, Bhubaneswar, Odisha, India
}

\begin{abstract}
The spread of pandemic Covid-19 has drastically disrupted every aspects of human life including education. It has created an unprecedented test on education. In many educational institutions around the world, campuses are closed and teaching-learning has moved online. Internationalization has slowed down considerably. In India, about 32 crore learners stopped to move schools/colleges and all educational activities brought to an end. Despite of all these challenges, the Higher Education Institutions (HEIs) have reacted positively and managed to ensure the continuity of teaching-learning, research and service to the society with some tools and techniques during the pandemic. This article highlights on major impacts of Covid-19 on HEIs in India. Some measures taken by HEIs and educational authorities of India to provide seamless educational services during the crisis are discussed. Due to Covid-19 pandemic, many new modes of learning, new perspectives, new trends are emerged and the same may continue as we go ahead to a new tomorrow. So, some of the post Covid-19 trends which may allow imagining new ways of teaching learning of higher education in India are outlined. Some fruitful suggestions are also pointed to carry out educational activities during the pandemic situation.
\end{abstract}

Keywords: Covid-19, higher education, impact, India, post Covid-19

\section{Introduction}

On March 11, 2020 World Health Organisation (WHO) declared Covid-19 as a pandemic. Covid-19 has affected more than 4.5 million peoples worldwide (WHO). In India, the first affected case of Covid-19 was detected on 30 January 2020 in the state of Kerala and the affected had a travel history from Wuhan, China (Wikipedia). In India, the first death was reported on March 12, 2020 and the nation observed Janta Curfew for a day on March 22, 2020. India again observed 14 hours Janta Curfew on March 24 to combat the Coronavirus pandemic and assess the country's ability to fight the virus. Then, the $1^{\text {st }}$ phase of lockdown was announced by the Prime Minister on March 25, 2020 for 21 days. Monitoring the effects of the virus, Indian Government has been extending the lockdown period in different phases and the lockdown 5.0 was declared on April 30 which is effective from $1^{\text {st }}$ June to $30^{\text {th }}$ June 2020 . In all the phases of lockdown starting from lockdown1.0 to lockdown 5.0, the educational institutions throughout the nation have never got any relaxation to start their educational activities. Thus, pandemic Covid-19 impacted significantly on the education sector. According to the UNESCO report, Covid-19 has affected nearly $68 \%$ of total world's student population as per the data taken during $1^{\text {st }}$ week of June 2020. Outbreak of Covid-19 has impacted about 1.2 billion students and youths across the globe by school and university closures. Several other countries have also implemented localized closures impacting millions of additional learners. In India, more than 32 crores of students have been affected by the various restrictions and the nationwide lockdown for Covid-19 (Wikipedia). Most Governments around the world have temporarily closed educational institutions in an attempt to control the spread of the pandemic Covid-19. This worldwide closure has impacted drastically the world's student population. Governments around the world are making efforts to diminish the immediate impact of closure of educational institutions particularly for more vulnerable and disadvantaged communities and trying to facilitate the continuity of education for all using different digital modes of learning. According to a survey report of the Ministry of Human Resource Development (MHRD), Government of India, conducted on higher education it was observed that there are 993 universities, 39931 Colleges and 10725 standalone institutions listed on their portal, which contribute to education (DNS Kumar, 2020). Even though the country has been adapting to the new-age learning, but there still lies an obstacle in achieving entire success as only 45 crore people of our total population of the country have access to the internet/e-learning. The people residing in rural areas are still very much deprived of the technologies and therefore hampering the cause of online education. The Covid-19 pandemic taught the entire society on how necessity is the mother of invention by allowing educational institutions to adopt online learning and introduce a virtual learning culture. The pandemic has been steering the education sector forward with technological innovation and advancements. The pandemic has significantly disrupted the higher education sector. A large number of Indian students who are enrolled in many Universities abroad, especially in worst affected countries are now leaving those countries and if the situation persists, in the long run, there will be a significant decline in the demand for international higher education also.

\section{Objectives}

The present study is focused on the following objectives

- Highlight the impact of Covid-19 on higher education sector.

- Enlighten various emerging approaches of India for higher education

- Enlist post Covid-19 trends of HEIs 
- Put few suggestions for continuing educational activities of HEIs facing the challenges created by Covid-19.

\begin{abstract}
Methodology
Various reports of national and international agencies on Covid-19 pandemic are searched to collect data for current study. As it is not possible to go outside for data collection due to lockdown, information are collected from different authentic websites, journals and e-contents relating to impact of Covid-19 on higher educational system of India.
\end{abstract}

\section{Impact on Higher Education}

Pandemic Covid-19 has severely affected the total educational system of India as well as the globe but some of the most impacted areas of higher education of India are as pointed below.

1. Destabilized all educational activities: Outbreak of Covid-19 has compelled lockdown in every sector including education. The institutions got closed with cease of educational activities and created many challenges for the stake holders (Pravat, 2020a). So, the various activities like admission, examinations, entrance tests, competitive examinations conducted by various boards/schools/colleges/ universities are postponed. Many entrance tests for higher study got cancelled which created a great challenge in the life of a student of higher education. The primary challenge was to continue teaching learning process when students, faculties and staff could no longer be physically present on the campuses. The obvious solution for the institutions was to depend online teaching learning. However, within a relatively short time, HEIs have been able to provide support to the students through online modes. Covid-19 has accelerated adoption of digital technologies to deliver education. It encouraged all teachers and students to become more technology savvy. The HEIs have started conducting orientation programmes, induction meetings and counselling classes with the help of different e-conferencing tools like Google Meet, Skype, Youtube live, Facebook live, WebEx etc. to provide support services to the students. This initiative has taken to create an effective virtual environment of teaching learning and to create motivation among students for online activities. The teachers and students improved the use of electronic media for sharing information by making use of WhatsApp, Google drive, Telegram, Twitter etc. (Pravat, 2020b). They have been sharing important documents with the group members and creating online local repository also. Students are advised to submit the scanned copies of the assignments to the institution through email. Institutions have also started receiving internship reports and projects through email during the lockdown for Covid-19.

2. Mixed impact on Academic research \& Professional Development: Covid-19 has both negative and positive impacts on research. If we take the negative side, it has made impossible for researchers to travel and work together with others nationally and internationally. Some joint research work or project work are made complicated to complete. Some scientific laboratory testing/research work could not be conducted. If we look at the positive side, academicians got much time to improve their theoretical research work. Academicians got acquainted with technological methods and improved their research. Webinars and e-conferences became normal methods for sharing expertise among students and academicians around the globe with similar issues. They could get much time to concentrate on professional development by doing research and to improve knowledge by sharing ideas through webinars and e-conferences. They enhanced their technical skill and could get the scope for publishing articles in journals, publishing books in this free time.

3. Severely affected the educational assessment system: Most of the external examinations have been postponed and almost all the internal assessments have been cancelled. The cancellation of assessments has negative impact on students' learning. Many institutions have been managing the internal assessments through online mode using different digital tools but the postponement of the external assessments, has a direct impact on the educational and occupational future of students' life. This uncertainty has created anxiety among students as they are stuck in the same grade/class without promotion. Similarly, many students who had appeared final/board examinations would suffer a lot as by the time they get their certificates, it might be too late for them to apply for the forthcoming academic year in other countries due to lockdown.

4. Reduced employment opportunities: Many entrance tests job recruitments got cancelled which created negative impact with a great challenge in the life of a student of higher education. The Indians who have been doing their jobs abroad became upset of their job withdrawal also. In India, there is no recruitment in Govt. sector and fresh graduates are in pressure of fearing withdrawal of job offers from corporate sectors because of the pandemic situation. Many students may lose their jobs from India and overseas. The pass out students may not get their job outside India due to various restrictions caused by Covid-19. All these facts imply towards increase of unemployment rate due to this pandemic. With increase of unemployment situation, the interest for education may gradually decrease as people struggle for food rather than education (Pravat, 2020b).

\section{Emerging approaches of India for Higher Education during Covid-19}

Many challenges are created by Covid-19. The HEIs have responded positively and adopted various strategies to face the crisis during the pandemic. The Government of India has also taken number of preventive measures to prevent spread of pandemic Covid-19. The MHRD and University Grants Commission (UGC) have made several arrangements by lunching of many virtual platforms with online depositories, e-books and other online teaching/learning materials, educational channels through Direct to Home TV, Radios for students to continue their learning. During lockdown, students are using popular social media tools like WhatsApp, Zoom, Google meet, Telegram, Youtube live, Facebook live etc. for online teaching learning system. ICT initiative of MHRD (e-Broucher- https://mhrd.gov.in/ictinitiatives) is also a unique platform which combines all 
digital resources for online education (Pravat, 2020a). UGC has released Guidelines on Examinations and Academic calendar in view of COVID-19 pandemic and subsequent lockdown on $29^{\text {th }}$ April, 2020 (UGC notice). All terminal examinations have been postponed and shifted to July 2020 and suggested commencement of classes from August 2020. UGC has also prepared complete calendar for the academic session 2020-2021with new dates keeping in view of the lockdown. Some of the digital initiatives of UGC \& MHRD for higher education during COVID-19 are pointed as below:

- e-GyanKosh (http://egyankosh.ac.in/) is a National Digital Repository to store and share the digital learning resources which is developed by the Open and Distance Learning Institutions of India. Items in eGyanKosh are protected by copyright, with all rights reserved by Indira Gandhi National Open University (IGNOU).

\section{- Gyandarshan}

(http://www.ignouonline.ac.in/gyandarshan/) is a webbased TV channel devoted to educational and developmental needs for Open and Distance Learner. A web-based TV channel devoted to educational and developmental needs of the society

- Gyandhara (http://ignouonline.ac.in/Gyandhara/) is an internet audio counseling service offered by IGNOU. It is a web radio where students can listen to the live discussions by the teachers and experts on the topic of the day and interact with them through telephone, email (gyandhara@ignou.ac.in) and through chat mode.

- Swayam provides Massive Open Online Courses (MOOCs) with 140 universities approved credit transfer feature. Swayam Prabha provides high quality educational programs through 32 DTH channels transmitting educational contents. e-PG Pathshala (https://epgp.inflibnet.ac.in/) is for postgraduate students. Postgraduate students can access this platform for e-books, online courses and study materials. The details of these three digital plat forms are described by the author in the previous paper (Pravat, 2020b).

- e-Adhyayan (e-Books) is a platform that provides 700+ e-Books for the Post-Graduate courses. All the e-Books are derived from e-PG Pathshala courses. It also facilitates play-list of video content.

- e-Pathya (Offline Access) is one the verticals of e-PG Pathshala which is software driven course/content package that facilitates students pursuing higher education (PG level) in distance learning as well as campus learning mode. It also facilitates offline access.

- National Digital Library of India (NDLI) (https://ndl.iitkgp.ac.in/) is a repository of e-content on multiple disciplines for all kinds of users like students (of all levels), teachers, researchers, librarians, library users, professionals, differently-abled users and all other lifelong learners. It is being developed at Indian Institute of Technology Kharagpur. It is designed to help students to prepare for entrance and competitive examinations, to enable people to learn and prepare from best practices from all over the world and to facilitate researchers to perform inter-linked exploration from multiple sources. It is a virtual repository of learning resources with a single-window search facility. It is also available to access through mobile apps.

- e-Yantra (https://www.e-yantra.org/) provides hands on experience on embedded systems. It has about 380 Lab and made 2300+ colleges benefited.

- FOSSEE (https://fossee.in/) is short form for Free/Libre and Open Source Software for Education, which is developed to promote open source software for education as well as professional use.

- Virtual Labs (http://www.vlab.co.in/) has developed web-enabled curriculum based experiments designed for remote operation. It has over 100 Virtual Labs consisting of approximately 700+ web-enabled experiments which are designed for remote-operation. It provides remote-access to Labs in various disciplines of Science and Engineering. These Virtual Labs caters to students at the undergraduate level, post graduate level as well as to research scholars.

- e-ShodhSindhu (https://ess.inflibnet.ac.in/) is a collection of e-journals, e-journal archives and e-books on long-term access basis. It has 10,000+e-journals, $31,35,000+$ e-books. It provides access to qualitative electronic resources including full-text, bibliographic and factual databases to academic institutions at a lower rate of subscription.

- Shodhganga (https://shodhganga.inflibnet.ac.in/) is a platform for research students to deposit their Ph.D. theses and make it available to the entire scholarly community in open access. The repository has the ability to capture, index, store, disseminate and preserve Electronic Theses and Dissertations submitted by the researchers.

- VIDWAN (https://vidwan.inflibnet.ac.in/) is a premier database and national research network which has profiles of scientists/researchers and other faculty members working at leading academic institutions and other Research \& Development organisations in India.

- National Educational Alliance for Technology (NEAT)(https://neat.aicte-india.org/) is an initiative for skilling of learners in latest technologies through a Public-Private partnership model between the Government (through its implementing agency AICTE) and the Education Technology companies of India. It brings the best technological products in education pedagogy on a single platform for the convenience of learners.

- SAKSHAT (https://sakshat.ac.in/) is one Stop Education Portal for addressing all the education and learning related needs of students, scholars, teachers and lifelong learners. The portal provides the latest news, press releases, achievements etc related to Ministry of HRD. So one can visit SAKSHAT to know the world of online learning.

\section{Post Covid-19 Trends of Higher Education}

Change is inevitable which has been forced upon the society due to Covid-19. The opportunities created by the pandemic Covid-19 will lead towards a better tomorrow. Tomorrow will be a new morning which will entirely be in our own hands. New technologies will certainly challenge the traditional paradigms such as classroom lectures, modes of learning and modes of assessment. The new trends will allow the education sector to imagine new ways of teaching learning and some trends may be pointed as below.

1. May encourage personalised learning: Learning may not be confined to classes or to any specific boundaries. 
Students may be the virtual learners with one teacher leading dozens of students in the new age. The learning modules may be modified to suit different learning styles and the learning contents may come from different sources to meet the learners' aspirations and needs. Students may pursue their learning in the new paradigm as per their choice.

2. Student Attendance may slow down: Many parents may be reluctant to send back their children to schools/colleges suddenly after the end of lockdown. Some poor family parents who have lost their livelihood during the pandemic may not be able to afford the expenditure to send their children to institutions. This may lead to home education for another few months.

3. National and International student mobility for higher study may be reduced: Student safety and well-being issues are important deciding factors for students and their parents for movement to international institutions for higher study. New modes of social distancing will continue for quite some time and may affect on-campus face to face teaching learning. Most of the parents will prefer to find workable alternatives closer to their home and may restrict for less movement within the country due to the pandemic. The international education has also been affected by the crisis. Many international universities have been closed and are delivering all educational activities online. Many international conferences in higher education have been cancelled or turned into a series of webinars. So, the national and international student movement may be diminished.

4. Learning with social distancing may continue. All will maintain social distancing and avoid warm handshake, hug, personal greeting, and intimacy for a long time. Invisible restrictions may constraint the fun $\&$ joy of campus life. Sports, Gyms, tournaments may be in low gear for a longer period resulting less physical activities of students.

5. Educational institutions may run with different shifts per day. The need for social distancing may imply lesser students in each class. So, most of the educational institutions may work in different shifts per day which may put more pressure on the teaching and administrative staff of the institution to manage.

6. May raise the gap between privileged and unprivileged students Learners from low-income families and disadvantaged groups are the more likely to suffer as they may not afford high-speed internet connection and required technical gadgets for online learning. It will widen the gap between privileged and unprivileged learners creating inequality.

7. Teaching learning may run with technology. More and more students will depend on technology and digital solutions for teaching learning, entertainment and connecting themselves with the outside world. Students will use internet technology to communicate virtually with their teachers and fellow learners through E-mail, WhatsApp, Videoconference, Instant message, webinar or any other tool.

8. Assessment system may be changed to new shape. Artificial Intelligence (AI) may help teachers to deal with assessment, evaluation, preparing mark-sheets and monitoring the performance of each student easily. AI may use digital platform extensively to reduce burden of examiner in handling examination and evaluation systems. If these activities are made simpler, the academicians would be able to concentrate more on course development, qualitative teaching-learning and skill development.

9. Demand for Open and Distance Learning (ODL) and online learning may grow. Covid-19 has forced the human society to maintain social distancing. It has created more challenges to continue teaching learning by maintaining social distancing. To meet these challenges there is more demand for ODL and online modes of education and the same trend may continue in future also.

10. Blended learning may take the leading role. Blended learning combines both face to face and online learning modes. Covid-19 has accelerated adoption of digital technologies to deliver education and encouraged the educational institutions to move towards blended mode of learning. All teachers and students became more technology savvy. The traditional face to face mode with post Covid-19 technology mode will lead the education towards blended mode of teaching learning and it may transform the structure of the education system.

11. Student debt crisis may rise. In India, lots of students or their parents take education loans for higher education. If the employment market does not pick up, student debt crises may rise and create serious issue. Students may face increased stress, anxiety and depression due to their student loans.

12. Unemployment rate is expected to be increased. There is no recruitment in Govt. sector and fresh graduates fear withdrawal of their job offers from private sectors because of the pandemic Covid-19 (Pravat, 2020b). Many Indians might have returned home after losing their jobs overseas due to Covid-19. Hence, the fresh students who are likely to enter the job market shortly may face difficulty in getting suitable employment.

\section{Suggestions}

1. Educators and learners should be trained to utilise online teaching learning process using technology. Policy should be adopted by Government/educational institutions to provide free internet and free digital gadgets to all learners in order to encourage online learning as a result of which people would get engaged and remain safe during pandemic (Pravat, 2020c).

2. Immediate measures are required to lessen the effects of the pandemic on job offers, internship programs, and research projects.

3. Many online learning platforms offer multiple programmes on the same subjects with different levels of certifications, methodology and assessment parameters. So, the quality of programmes may differ across different online learning platforms. Therefore, establishment of quality assurance mechanisms and quality benchmark for online learning programmes must be developed and offered by HEIs in India keeping in view of rapid growth of the online learning platforms 
4. If the pandemic Covid-19 continues, new approaches for academic assessment should be adopted by educational institutions. Academic assessment of the students may be done through online mode or through quizzes and small projects.

5. Government should support HEIs to strengthen their resources to run virtual educational activities. Students also need to be supported with better access to internet and technology as most students are unable to afford the facilities. During this pandemic, the HEIs should focus more on virtual educational activities including television, radio and web-based education.

6. WHO has recently pointed out that the Covid-19 may never be eradicated and people will have to live with it. "It is important to put this on the table: this virus may become just another endemic virus in our communities, and this virus may never go away. HIV has not gone away, but we have come to terms with the virus. I think there are no promises in this and there are no dates. This disease may settle into a long problem, or it may not be" WHO emergencies expert Mike Ryan said in an online briefing (Sandhya, 2020). With reference to this statement, many countries are now planning to continue education through distance or virtual mode and India should plan for the same also.

7. Across the globe, Indian traditional knowledge is well known for its scientific innovations, values and benefits to develop sustainable technologies and medicines and this knowledge systems in different fields should be integrated with a present-day mainstream higher education system.

\section{Conclusions}

This study has outlined various impacts of Covid-19 on higher education in India. The recent pandemic created an opportunity for change in pedagogical approaches and introduction of virtual education in all levels of education. As we do not know how long the pandemic situation will continue, a gradual move towards the online/virtual education is the demand of the current crisis. UGC and MHRD have lunched many virtual platforms with online depositories, e-books and other online teaching/learning materials. Combination of the traditional technologies (radio, TV, landline phones) with mobile/web technologies to a single platform with all depositories would enhance better accessibility and flexibility to education. This would involve upgrading the service platform to enable it to meet the required volume of educational demands of students. All service providers need to be mobilized to provide proper access to the educational service platforms to the disadvantaged groups of population also. Virtual education is the most preferred mode of education at this time of crisis due to the outbreak of Covid-19. The post Covid-19 education seems to be an education with widely accepted online/virtual education which may perhaps be a parallel system of education. This paper has not covered any statistical analysis on impact of Covid-19 on higher education however further in-depth study with statistical research may also be undertaken.

\section{References}

1. WHO. WHO Coronavirus Disease (COVID-19) Dashboard. Retrieved on June 3, 2020. from https://covid19.who.int/

2. Wikipedia. Covid-19 Pandemic in India. Retrieved on May 20, 2020 from https://en.wikipedia.org/wiki/COVID19_pandemic_in_India

3. Wikipedia, Education in India Retrieved on May 24, 2020. from https://en.wikipedia.org/wiki/Education_in_India

4. UNESCO. COVID-19 Educational Disruption and Response. Retrieved on June 3, 2020 from https://en.unesco.org/covid19/educationresponse

5. DNS Kumar (29 April 2020). Impact of COVID-19 on Higher Education. Retrieved on May 25, 2020 from https://www.highereducationdigest.com/impact-ofcovid-19-on-higher-education/

6. Pravat $\mathrm{Ku}$ Jena. Challenges and Opportunities created by Covid-19 for ODL: A case study of IGNOU. International Journal for Innovative Research in Multidisciplinary Filed. 2020a; 6(5):217-222.

7. Pravat Ku Jena. Impact of Pandemic COVID-19 on Education in India. Purakala. 2020b; 31(46):142-149.

8. MHRD notice (20 March, 2020). COVID-19 Stay Safe: Digital Initiatives. Retrieved on May 25, 2020. from https://www.mohfw.gov.in/pdf/Covid19.pdf

9. MHRD online. Online Learning Resources of MHRD. Retrieved on June 6, 2020 from https://mhrd.gov.in/sites/upload_files/mhrd/files/upload _document/Write_up_online_learning_resources.pdf

10. UGC notice (29 April, 2020). UGC Guidelines on Examinations and Academic Calendar in view of COVID-19 Pandemic Retrieved on June 5, 2020. from https://www.ugc.ac.in/pdfnews/5369929_Letterregarding-UGC-Guidelines-on-Examinations-andAcademic-Calendar.pdf

11. Pravat $\mathrm{Ku}$ Jena. Online learning during lockdown period for Covid-19 in India. International Journal of Multidisciplinary Educational Research. 2020c; 9, 5(8):82-92.

12. Sandhya Ramesh. What it means for Covid to never go away and become endemic- like HIV, malaria, measles, 2020. Retrieved on June 2, 2020 from https://theprint.in/health/what-it-means-for-covid-tonever-go-away-and-become-endemic-like-hiv-malariameasles/423217/ 